\title{
International Experience of Interest Rate Liberalization and China's Investigation
}

\author{
Yuanxin Zhang \\ Chengdu Institution of New Economic Development \\ Chengdu, China
}

\begin{abstract}
The 19th National Congress of the People's Republic of China has made significant progress in the reform of interest rate and exchange rate liberalization, steadily promoting the internationalization of RMB. At present, there are still many restrictive factors that prevent the formation of a substantive, effective and market-oriented interest rate formation and control mechanism and hinder the steady progress of RMB internationalization. This paper puts forward some countermeasures to solve the problems by analyzing and interpreting the main restricting factors and referring to some representative cases of some countries in the process of interest rate liberalization reform.
\end{abstract}

Keywords-interest rate liberalization; international experience; countermeasures

\section{INTRODUCTION}

Interest rate liberalization is an important part of China's socialistic economic system reform. Interest rate liberalization refers to the process in which the level and structure of interest rate are independently determined by economic subjects in a market economy. In essence, it is a process in which market mechanism plays a role in interest rate determination step by step, and then capital flow and allocation are continuously optimized. To get through the transmission mechanism of interest rate, the integration of the dual-track interest rate determination mechanism is the main work of China's interest rate liberalization. This paper focuses on the experiences of some representative countries in interest rate reform liberalization, analyzes and tests the problems of current situation in China's interest rate liberalization and tries to put forward optimized suggestions to facilitate the final stage of China's interest rate liberalization reform.

\section{CURRENT SituATION AND OBSTACLES OF INTEREST RATE LIBERALIZATION IN CHINA}

\section{A. Current Situation of Interest Rate Liberalization in China}

Firstly, in fact of deposit and loan interest rate, China has completely liberalized the upper limit of RMB loan interest rate and deposit interest rate of financial institutions since 2004. In 2013, the lower limit of loan interest rate and control on bill discount interest rate were basically abolished, and the control on loan interest rate of financial institutions was fully relaxed. These mark the basic realization of China's loan interest rate liberalization.

Secondly, for currency market interest rate liberalization, the interest rate marketization in China's money market is progressing smoothly. It has mainly gone through three stages of interbank lending rate marketization, bond market interest rate marketization and Shibor as the benchmark interest rate in the money market which construct the market interest rate system.

Last but not the least, in aspect of central bank interest system, the central bank's control of interest rates has gradually changed from direct to indirect in China's interest rate liberalization reform.

\section{B. Obstacles of China's Interest Rate Liberalization Reform}

1) Market interest rate self-regulatory pricing mechanism exists implicit control: Theoretically, China has liberalized the upper limit of deposit and loan interest rates and basically completed the market-oriented reform of interest rates. However, in practice, China has established a three-level self-regulatory mechanism for interest rate pricing at the national, provincial and municipal levels, which still provides guidance for pricing schemes of small and medium-sized financial institutions with weak independent pricing ability. To some extent, the interest rate ceiling is still affected by the self-discipline mechanism of the industry.

2) China's benchmark interest rate formation mechanism is not standardized: Currently, Shanghai interbank offered rate is mainly adopted as the benchmark interest rate in China with 16 quotation Banks with high credit rating participating in the quotation. However, the rating of quotation institutions is not completely equal, and the market segmentation and SHIBOR are greatly affected by the Repo rate, which cannot reflect the real price of capital. Because interest rates transmission mechanism cannot fully take effect, the benchmark interest rate formation mechanism is not sound.

3) With bank's risk increasing, risk control ability is insufficient to match the needs of enterprises: In the process of interest rate liberalization, banks are faced with rising credit risk, market risk and operational risk. In addition, 


\section{INTERNATIONAL EXPERIENCES AND ENLIGHTENMENT OF INTEREST RATE LIBERALIZATION}

sensitivity to interest rates and risk awareness, and poor risk control ability. After the liberalization of the loan interest rate, banks have to increase the financing cost and risk of enterprises in order to pursue higher profit returns.

4) Imperfection of the financial market development and unsound financial supervision mechanism exist: For the financial market, it is still heavily segmented and unbalanced with lack of financial products. Banks still occupy the dominant position, and the interest rate market space for non-bank is small. Besides, the number of institutional investors is insufficient, which hinders the formation of a complete market interest rate system.

\section{A. Interest Rate Liberalization Reform Model and Effects in Various Countries}

In 1970s, the disadvantages of interest rate control became increasingly exposed. Under the guidance of financial deepening theory, a wave of financial liberalization with interest rate market as the core has been launched. "Progressive" interest rate liberalization is represented by the United States, Japan and South Korea, and "radical" interest rate liberalization is represented by Latin America.

Seven representative countries including the United States, United Kingdom, Australia, Japan, Thailand, Chile and Uruguay are selected as the research objects. In order to ensure the systematicness and scientificalness of research, the effects of interest rate liberalization reform in these seven countries are analyzed by sorting out the time points and landmark events of interest rate liberalization and opening (See "Table I").

TABLE I. THE OPEN SCHEDULE AND LANDMARK EVENTS OF INTEREST RATE LIBERALIZATION IN VARIOUS COUNTRIES

\begin{tabular}{|l|l|l|}
\hline Nation & \multicolumn{1}{|c|}{ Time } & \multicolumn{1}{c|}{ Landmark event } \\
\hline USA & Mar 1986 & Successfully abolished the Q regulations \\
\hline UK & Oct 1971 & Introduced financial reform and scraped the interest-rate agreement \\
\hline AUS & 1981 & Canceled the direct controls on deposit and loan interest rates \\
\hline JPN & Oct 1994 & $\begin{array}{l}\text { Liberalized marketization of deposit and loan interest rates and completely liberalized the } \\
\text { interest rates control }\end{array}$ \\
\hline THA & Jun 1989 & Commercial bank's one-year deposit interest rate cap was lifted \\
\hline CHI & Apr 1975 & Eliminated all interest rate controls \\
\hline URY & Sep 1974 & Raised the legal interest rate cap on deposits and loans \\
\hline
\end{tabular}

1) The changes of GDP growth rate before and after interest rate liberalization: By comparing the changes of GDP growth rate before and after interest rate liberalization in seven countries, there are three points as follow shown in "Table II".

Firstly, after interest rate liberalization, the GDP growth rate shows a downward trend in the overall stability with a good performance, such as United States, Britain, Japan and Thailand. America's GDP growth rate tends to be stable. Interest rate presents a modest rise at first, then begins to decline, and the average GDP growth rate for five years before and after the liberalization of interest rate are $3.36 \%$ and $2.64 \%$ respectively, which has reduced $21 \%$. Besides, Britain's GDP rate is relatively slow, but it keeps a steady decline after interest rate liberalization. Although the GDP growth rate of Thailand has been declining since the interest rate liberalization, it remains stable at about $8 \%$.
Secondly, after interest rate liberalization, GDP growth rate fluctuates, such as Australia and Uruguay. Australia's GDP growth rate decreases from $3.35 \%$ to $-2.23 \%$. But after interest rate liberalization, it has increases to $5.23 \%$ in the fourth year and decreases to $3.93 \%$ in the fifth year, showing a small wavy change. Uruguay's GDP growth rate increases to $6.09 \%$ after the reform, decreases to $1.46 \%$ from $6.09 \%$ in the second year, and recovers to $6.19 \%$ from $1.46 \%$ in the third year.

Thirdly, after interest rate liberalization, GDP growth rate increases significantly, such as Chile. Interest rate liberalization has injected new vitality into Chile's GDP growth. In the five years after interest rate liberalization, the GDP growth rate has increased by $400 \%$ compared with that of the previous five years.

TABLE II. NAtional GDP Growth Situation Before AND AFter the Marketization of Interest Rate (Percentage)

\begin{tabular}{|l|l|l|l|l|l|l|l|}
\hline & \multicolumn{1}{|c|}{ USA } & \multicolumn{1}{c|}{ UK } & \multicolumn{1}{|c|}{ AUS } & \multicolumn{1}{|c|}{ JPN } & \multicolumn{1}{|c|}{ THA } & \multicolumn{1}{c|}{ CHI } & \multicolumn{1}{c|}{ URY } \\
\hline-5 & 2.5949 & 2.0493 & 2.5871 & 5.3702 & 5.7524 & 2.1225 & 5.8647 \\
\hline-4 & -1.9106 & 2.3110 & 3.6081 & 5.5724 & 4.6472 & 9.0180 & 2.3332 \\
\hline-3 & 4.6327 & 3.9847 & 0.8975 & 3.3243 & 5.5338 & -0.8192 & -0.2517 \\
\hline-2 & 7.2590 & 2.0524 & 4.0537 & 0.8190 & 9.5189 & -4.9411 & -1.3196 \\
\hline-1 & 4.2393 & 2.6682 & 3.0513 & 0.1711 & 13.2881 & 2.4938 & 0.2752 \\
\hline 0 & 3.5119 & 2.0814 & 3.3568 & 0.8636 & 12.1905 & -11.3628 & 2.8953 \\
\hline
\end{tabular}




\begin{tabular}{|l|l|l|l|l|l|l|l|}
\hline & \multicolumn{1}{|c|}{ USA } & \multicolumn{1}{c|}{ UK } & \multicolumn{1}{c|}{ AUS } & \multicolumn{1}{c|}{ JPN } & \multicolumn{1}{c|}{ THA } & \multicolumn{1}{c|}{ CHI } & URY \\
\hline 1 & 3.4615 & 3.6187 & 3.3235 & 1.9423 & 11.1672 & 3.4064 & 6.0969 \\
\hline 2 & 4.2036 & 7.2449 & -2.2336 & 2.6101 & 8.5583 & 8.6974 & 3.9355 \\
\hline 3 & 3.6809 & -1.5845 & 4.6307 & 1.5956 & 8.0834 & 7.4629 & 1.4555 \\
\hline 4 & 1.9187 & -0.5563 & 5.2493 & -2.0031 & 8.2510 & 8.6823 & 5.3740 \\
\hline 5 & -0.0727 & 2.7716 & 3.9327 & -0.1993 & 8.9872 & 8.1486 & 6.1991 \\
\hline AVE & 3.0472 & 2.4219 & 2.9507 & 1.8242 & 8.7253 & 2.9917 & 2.9871 \\
\hline
\end{tabular}

a. Note: 0 years is the year of interest rate marketization; for the $-\mathrm{i}$ years before opening; for the -i years after opening( $i=1,2,3,4,5)$; Source: World bank database

2) Analysis on the changes of inflation in various countries before and after interest rate liberalization: In terms of inflation, GDP deflator is selected to measure the inflation (See "Table III"). The performances of inflation before and after interest rate liberalization are different in different countries. In United States, Britain, Japan, Thailand and Australia, the fluctuations of inflation before and after interest rate liberalization are small and relatively stable. In contrast, in Chile, after the reform of the interest rate, the inflation situation has eased significantly. For Uruguay, inflation is higher before the reform of the interest rate market. Although it has eased after the reform of the interest rate market, it still remains at the high level.

TABLE III. INFLATiOn RATES Before AND AFter the MARKETiZATION OF INTEREST RATE (PERCENTAGE)

\begin{tabular}{|l|l|l|l|l|l|l|l|}
\hline & USA & \multicolumn{1}{|c|}{ UK } & \multicolumn{1}{|c|}{ AUS } & JPN & THA & CHI & \multicolumn{1}{|c|}{ URY } \\
\hline-5 & 9.3341 & 4.3187 & 14.0080 & 2.2266 & 1.4479 & 40.6937 & 27.0723 \\
\hline-4 & 6.2055 & 2.8878 & 11.4150 & 2.2646 & 2.1772 & 18.2556 & 4.1994 \\
\hline-3 & 3.9468 & 4.2071 & 8.2283 & 2.6057 & 1.6532 & 85.5439 & 31.6850 \\
\hline-2 & 3.5496 & 5.4516 & 8.6323 & 1.5882 & 4.7232 & 414.0067 & 69.1685 \\
\hline-1 & 3.1981 & 7.8853 & 10.0121 & 0.4374 & 5.9184 & 665.3848 & 191.5628 \\
\hline 0 & 2.0169 & 9.2746 & 9.5225 & 0.1150 & 6.1167 & 334.6455 & 28.4884 \\
\hline 1 & 2.5524 & 8.0484 & 11.7210 & -0.7253 & 5.7732 & 250.6097 & 65.9766 \\
\hline 2 & 3.5010 & 7.2765 & 10.1555 & -0.5569 & 5.7465 & 105.7907 & 47.2911 \\
\hline 3 & 3.8884 & 15.0325 & 7.8709 & 0.5951 & 4.4904 & 57.6640 & 55.6066 \\
\hline 4 & 3.7000 & 27.0413 & 4.6215 & -0.0545 & 3.2869 & 45.7291 & 46.8017 \\
\hline 5 & 3.3261 & 15.1018 & 6.6493 & -1.2737 & 5.2079 & 28.7645 & 79.2081 \\
\hline AVE & 4.1108 & 9.6842 & 9.3488 & 0.6566 & 4.2310 & 186.0989 & 58.8237 \\
\hline
\end{tabular}

a. Note: 0 year is the year of interest rate marketization; for the -i years before opening; for the -i years after opening $i=1,2,3,4,5)$; The inflation rate by the GDP deflator measures; Source: World bank

3) Analysis on the change of capital market scale before and after interest rate liberalization: "Table IV" describes the changes of capital market scale before and after interest rate liberalization in each country with financial deepening rate. Different countries have different influences on the financial deepening rate (M2 in GDP). For the USA, UK, Australia and Japan, the effects of interest rate liberalization on the financial deepening rate are very small with occasional slight fluctuations. In Thailand and Uruguay, the proportions of M2 in GDP present steady growth trends after interest rate liberalization. The financial deepening rate of Chile is not clear due to the influence of interest rate liberalization, but the proportion of M2 in GDP fluctuates greatly.

TABLE IV. M2 Before AND AFter the MARKETIZATION OF INTEREST RATE AS A SHARE OF GDP (\%)

\begin{tabular}{|l|c|c|c|c|c|c|c|}
\hline & USA & UK & AUS & JPN & THA & CHI & URY \\
\hline-5 & 69.3143 & 35.0305 & 43.9194 & 189.3124 & 59.5615 & 14.8134 & 19.7454 \\
\hline-4 & 73.2105 & 36.8599 & 40.2996 & 187.3644 & 62.0899 & 23.2059 & 21.9240 \\
\hline-3 & 72.8799 & 36.4575 & 40.7758 & 186.5373 & 65.7624 & 30.8390 & 25.2404 \\
\hline-2 & 73.8426 & 34.9317 & 40.2612 & 188.1223 & 68.4805 & 27.3928 & 25.4129 \\
\hline-1 & 74.3369 & 34.5120 & 40.4906 & 195.2466 & 67.3218 & 13.8731 & 14.5103 \\
\hline 0 & 76.9949 & 35.0262 & 39.3051 & 201.4484 & 71.3503 & 14.6460 & 18.2911 \\
\hline 1 & 75.5162 & 40.0140 & 37.6575 & 207.1610 & 76.1647 & 20.6769 & 20.6927 \\
\hline 2 & 74.7734 & 44.3574 & 39.5948 & 210.7450 & 79.2160 & 18.5574 & 26.9181 \\
\hline 3 & 73.1108 & 44.2485 & 39.1980 & 218.1889 & 81.0234 & 20.9835 & 30.9736 \\
\hline 4 & 71.0275 & 37.5252 & 41.9751 & 229.7572 & 86.2277 & 24.3100 & 38.3384 \\
\hline 5 & 69.8233 & 35.3931 & 41.4903 & 239.7206 & 83.2370 & 28.3728 & 37.3756 \\
\hline AVE & 73.1664 & 37.6687 & 40.4516 & 204.8731 & 72.7668 & 21.6064 & 25.4020 \\
\hline
\end{tabular}

a. Note: 0 year is the year of interest rate marketization; for the -i years before opening; for the -i years after opening( $i=1,2,3,4,5)$; M2 for the currency and the quasi currency; Source: World bank

Due to the different conditions of these countries, there are significantly different effects of interest rate liberalization reform in various countries. Developed countries, represented by the United States, Britain, Australia and Japan, have carried out interest rate liberalization reform in a "gradual" mode. The overall economic situation is in a stable 
healthy and stable macro environment promotes to enhance the interest rate leverage and price system ${ }^{1}$.

GDP growth rate before interest rate liberalization, inflation rate before interest rate liberalization, variation coefficient of GDP growth rate and inflation rate are selected to analyze to the stability of these countries, as shown in "Table V" and "Table VI". be seen that the effect of a country's interest rate liberalization reform is closely related to the macroeconomic conditions in the reform period, especially the stability of macroeconomic operation and the degree of financial development.

\section{B. Enlightenment from Experiences of Interest Rate Liberalization in Various Countries}

1) Interest rate liberalization needs a stable external environment: Interest rate liberalization reform is easy to succeed under stable macroeconomic environment. When macro environment is stable, government can response to requirement of financial regulation's changes calmly, which do not meet the requirements of real economic development and respond reasonably, so that the reform has a higher opportunity to success.

2) Relevant supporting regulatory policies should be improved: The reform of interest rate liberalization should enable market players to have ability to price capital freely, so as to promote effective allocation of resources and highquality economic growth, rather than simply deregulate interest rate control. Therefore, the base of fully liberalizing interest rate control is mature financial market. At the same time, according to the reform experience of various countries, economy situation in relatively small fluctuations in process of reform can monitor financial system closely and establish suitable regulatory system based on recent condition.

3) Supportive policies should be timely and appropriate: The more reasonable supportive policies at the right time is the foundation of further reform. Based on these successful experiences of United States, Japan and South Korea, the key point is that the government proposes supporting policies timely according to the actual needs of market subjects.

\section{EXTERNAL ENVIRONMENT TEST OF CHINA'S INTEREST RATE LIBERALIZATION REFORM}

\section{A. Quantitative Standards of External Environment for Interest Rate Liberalization Reform}

1) Stability of economic operation: A stable macroeconomic environment is the most important and basic prerequisite for developing countries to implement interest rate liberalization and the most fundamental carrier for the smooth operation of interest rate liberalization. When a country's economy changes from a planned economy to a market economy, market mechanism replaces the planned mechanism to play a dominant role in economic life. A
TABLE V. COEFFICIENT OF VARIATION OF GDP GROWTH RATE BEFORE AND AFTER INTEREST RATE LIBERALIZATION IN VARIOUS COUNTRIES (PERCENTAGE)

\begin{tabular}{|l|l|l|l|}
\hline Nation & $\begin{array}{c}\text { Coefficient of } \\
\text { variation in } \\
\text { preceding ten } \\
\text { years }\end{array}$ & $\begin{array}{c}\text { Coefficient of } \\
\text { variation in } \\
\text { preceding five } \\
\text { years }\end{array}$ & $\begin{array}{c}\text { Coefficient of } \\
\text { variation in } \\
\text { preceding three } \\
\text { years }\end{array}$ \\
\hline USA & 0.7452 & 0.9015 & 1.2098 \\
\hline UK & 0.3696 & 0.2764 & 0.7478 \\
\hline AUS & 0.3644 & 0.3840 & 1.0539 \\
\hline JPN & 0.5374 & 0.7341 & 1.3661 \\
\hline THA & 0.3871 & 0.4175 & 1.0786 \\
\hline CHI & 1.4212 & 2.9062 & 2.0449 \\
\hline URY & 2.1217 & 1.8382 & 0.8664 \\
\hline \multicolumn{2}{|c|}{ Note: Coefficient of variation=The standard deviation of the sample data/Sample } \\
mean; Source: World bank database.
\end{tabular}

TABLE VI. INFLATION BEFORE INTEREST RATE LIBERALIZATION (PERCENTAGE)

\begin{tabular}{|l|l|l|}
\hline National & $\begin{array}{c}\text { Average for } \\
\text { first 5 years }\end{array}$ & $\begin{array}{c}\text { Average for } \\
\text { first 3 years }\end{array}$ \\
\hline USA & 1.3384 & 2.1001 \\
\hline UK & 1.9306 & 2.6215 \\
\hline AUS & 2.4212 & 3.7523 \\
\hline JPN & 0.8383 & 0.9107 \\
\hline THA & 1.7399 & 2.1550 \\
\hline CHI & 176.3769 & 214.6192 \\
\hline URY & 46.8453 & 55.0857 \\
\hline \multicolumn{2}{|c|}{ a. NOTE: Source: World bank database. }
\end{tabular}

Through comparative analysis, it can be seen that for the countries with more steady macroeconomic environment, the coefficient of variation of GDP growth rate is small and below 1 , and the average inflation rate is below $4 \%$, such as the United States, Britain, Australia, Japan and Thailand. On the contrary, Latin American countries with unstable macroeconomic performance, the coefficient of variation of GDP growth is small and greater than 2, and the average inflation rate is above $4 \%$.

To sum up, macroeconomic stability has an impact on the market-oriented reform of interest rate. The quantitative criteria for macroeconomic stability are generally that the economy is relatively stable in 3-5 years, the coefficient of variation of GDP growth rate is below 1.0, and the average inflation rate is below $4 \%$.

2) Degree of financial market development: The financial deepening rate is chosen to study the development of capital market before interest rate liberalization (See

1 Zhu Sixiang, Wang Jing. Conditional Analysis of Interest Rate Liberalization in Developing Countries [J]. Journal of Economic Research, 2008(19):86-87. 
"Table VII"). Among them, the average financial deepening rates of the United States, Britain, Japan and Thailand, which have successfully reformed the interest rate liberalization, are above 50\%. Australia's financial deepening rate is around $40 \%$. However, the average financial deepening rate of Chile and Uruguay is below $25 \%$.

TABLE VII. AVERAGE FinANCIAL DEEPENING RATE OF COUNTRIES BEFORE INTEREST RATE MARKETIZATION (PERCENTAGE)

\begin{tabular}{|l|l|l|l|}
\hline Nation & $\begin{array}{c}\text { 10 years before } \\
\text { interest rate } \\
\text { liberalization }\end{array}$ & $\begin{array}{c}\text { 5 years before } \\
\text { interest rate } \\
\text { liberalization }\end{array}$ & $\begin{array}{c}\text { 3 years before } \\
\text { interest rate } \\
\text { liberalization }\end{array}$ \\
\hline USA & 71.0725 & 72.7168 & 73.6865 \\
\hline UK & 56.2713 & 55.5583 & 55.3004 \\
\hline AUS & 43.4191 & 41.1493 & 40.5092 \\
\hline JPN & 181.1305 & 189.3166 & 189.9687 \\
\hline THA & 54.8928 & 64.6432 & 67.1882 \\
\hline CHI & 17.6556 & 22.0248 & 24.0350 \\
\hline URY & 24.1202 & 21.3666 & 21.7212 \\
\hline \multicolumn{4}{|c|}{ NOTE: Financial deepening rate= M2/GDP; Source: World bank database }
\end{tabular}

Therefore, the level of financial deepening rate can reflect the development status and scale of a country's capital market. A country's financial market development degree is an important factor influencing the effect of interest rate marketization. Financial deepening rate reaching more than $50 \%$ is the quantitative standard of financial market development degree.

\section{B. External Environment Test of China's Interest Rate Liberalization Reform}

Because the level of financial deepening rate reflects the development status and scale of a country's capital market. A country's financial market development degree is also the important factors influencing the effect of interest rate marketization, which should reaches the requirements of financial deepening rate more than $50 \%$ to measure the financial market development degree, coefficient of variation of GDP growth rate below 1.0 and the average inflation rate below $4 \%$ quantitatively. (See "Table VIII")

TABLE VIII. ANALYSIS ON THE STABILITY OF CHINA'S MACROECONOMIC OPERATION IN RECENT 10 YEARS

\begin{tabular}{|l|l|l|l|}
\hline \multicolumn{1}{|c|}{ Annual } & \multicolumn{1}{c|}{ First 10 years } & First 5 years & First 3 years \\
\hline The average of GDP growth rate (\%) & 11.9203 & 8.8980 & 8.7161 \\
\hline Standard deviation of GDP growth rate (\%) & 4.6043 & 1.7403 & 2.2281 \\
\hline Coefficient of variation of GDP growth & 0.3862 & 0.1955 & 0.2556 \\
\hline Average rate of inflation (\%) & 3.4434 & 1.6322 & 1.6966 \\
\hline The standard deviation of the inflation rate (\%) & 3.3834 & 1.5952 & 2.1804 \\
\hline The coefficient of variation in the rate of inflation & 0.9827 & 0.9775 & 1.2851 \\
\hline
\end{tabular}

Note: The inflation rate is measured by GDP deflator; Data from 2008 to 2017; Source: World bank database.

For the test of China's macroeconomic stability, China's growth rate and inflation rate from 2008 to 2017 are used to analyzed ("Table VIII"). China's economy is growing steadily and rapidly, with an average GDP growth rate of $8.7 \%$ in the past three years. The coefficient of variation of GDP growth in recent three years is 0.2556 . However, the standard deviation of GDP growth rate is relatively large, and there is still a certain degree of fluctuation in the process of economic development. At the same time, nearly three years the average inflation rate of $1.7 \%$ is less than $4 \%$. While maintaining a medium-high growth rate, inflation is also at a relatively low level. So the macro economy is running smoothly. However, the standard deviation and coefficient of variation of the inflation rate are relatively large, which indicates that China's price level also fluctuates to a certain extent. (See "Table IX")

TABLE IX. GDP PER CAPITA OF EACH COUNTRY 1 YEAR BEFORE INTEREST RATE LiBERALIZATION

\begin{tabular}{|l|l|l|l|}
\hline \multicolumn{1}{|c|}{ Annual } & \multicolumn{1}{c|}{ First 10 years } & \multicolumn{1}{c|}{ First 5 years } & First 3 years \\
\hline The average of GDP growth rate(\%) & 11.9203 & 8.8980 & 8.7161 \\
\hline Standard deviation of GDP growth rate(\%) & 4.6043 & 1.7403 & 2.2281 \\
\hline Coefficient of variation of GDP growth & 0.3862 & 0.1955 & 0.2556 \\
\hline Average rate of inflation(\%) & 3.4434 & 1.6322 & 1.6966 \\
\hline The standard deviation of the inflation rate(\%) & 3.3834 & 1.5952 & 2.1804 \\
\hline The coefficient of variation in the rate of inflation & 0.9827 & 0.9775 & 1.2851 \\
\hline
\end{tabular}

From the perspective of economic development, although China has become the second largest economy in the world, the per capita GDP is still low. In 2017, China's per capita GDP was $9481.881^{2}$, far lower than that of Britain, the United States, Australia and Japan in the year before interest rate liberalization ("Table IX"). The level of economic development still needs to be improved. (See "Table X")

2 Note: data from SOHU

finance,https://www.sohu.com/a/214620888_687803 
table X. Financial Deepening Rate of Financial Market Development in China in Recent 10 Years (\%)

\begin{tabular}{|c|c|c|c|c|c|c|}
\hline Annual & $\mathbf{2 0 0 8}$ & $\mathbf{2 0 0 9}$ & $\mathbf{2 0 1 0}$ & $\mathbf{2 0 1 1}$ & $\mathbf{2 0 1 2}$ & Average over last 10 years \\
\hline M2/GDP & 66.4213 & 76.9770 & 78.4393 & 76.5571 & 81.2507 & 83.5002 \\
\hline Annual & $\mathbf{2 0 1 3}$ & $\mathbf{2 0 1 4}$ & $\mathbf{2 0 1 5}$ & $\mathbf{2 0 1 6}$ & $\mathbf{2 0 1 7}$ & Average over last 5 years \\
\hline M2/GDP & 84.6884 & 88.2438 & 92.2666 & 95.7706 & 94.3874 & 91.0714 \\
\hline
\end{tabular}

In aspect of the development degree of financial market

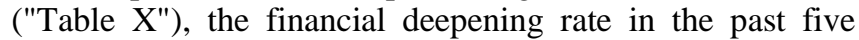
years is as high as $91.0714 \%$, much higher than the quantitative standard of financial deepening rate of $50 \%$. However, as China is a country with a high savings rate and less direct financing, most of funds are flowed into banks as savings deposits and time deposits to be part of M2. So the financial deepening rate is higher. As shown in "Table XI", total savings and quasi-currency increases year by year, and quasi-currency accounts for more than $60 \%$ of M2 in the recent ten years. For M2, nearly $70 \%$ is the quasi-currency of urban and rural residents' savings deposits, fixed deposits in enterprise deposits, trust deposits and other deposits which are relatively stagnant. Therefore, China's real financial deepening rate should be lower than $91 \%$, and there are still some problems in the development of capital market.

TABLE XI. RELEVANT INDICATORS OF CAPITAL Market DEVELOPMENT IN China IN RECENT 10 Years

\begin{tabular}{|l|l|l|l|l|l|}
\hline \multicolumn{1}{|c|}{ Annual } & $\begin{array}{c}\text { Total savings } \\
\text { (trillion yuan) }\end{array}$ & $\begin{array}{c}\text { Quasi currency } \\
\text { (trillion yuan) }\end{array}$ & $\begin{array}{c}\text { M2 } \\
\text { (trillion yuan) }\end{array}$ & $\begin{array}{c}\text { Total savings } \\
\text { /M2(\%) }\end{array}$ & $\begin{array}{c}\text { Quasi currency } \\
\text { /M2(\%) }\end{array}$ \\
\hline 2008 & 16.4408 & 344.0995 & 530.5667 & 3.0987 & 64.8551 \\
\hline 2009 & 17.4918 & 441.7052 & 671.7811 & 2.6038 & 65.7514 \\
\hline 2010 & 21.2696 & 519.7018 & 809.9461 & 2.6261 & 64.1650 \\
\hline 2011 & 24.2063 & 610.7968 & 936.4857 & 2.5848 & 65.2222 \\
\hline 2012 & 26.8842 & 756.2359 & 1097.6321 & 2.4493 & 68.8970 \\
\hline 2013 & 29.1263 & 883.4367 & 1260.2585 & 2.3111 & 70.0996 \\
\hline 2014 & 31.9774 & 1025.0282 & 1420.6680 & 2.2509 & 72.1511 \\
\hline 2015 & 33.3447 & 1159.4113 & 1589.4137 & 2.0979 & 72.9458 \\
\hline 2016 & 34.2099 & 1252.6020 & 1780.3419 & 1.9215 & 70.3574 \\
\hline 2017 & 37.3520 & 1343.1058 & 1951.7474 & 1.9138 & 68.8156 \\
\hline
\end{tabular}

To sum up, the external environment of China's current interest rate liberalization reform has reached quantitative standards. But there are still some problems to be solved, such as the fluctuation of macroeconomic development and the imperfect development of financial market.

\section{CONCLUSION}

This paper has studied the process and current situation of China's interest rate liberalization reform with other countries' experiences comparitively, and finds out that although China's interest rate liberalization reform is basically completed, there still exists some obstacles such as implicit control of the market interest rate self-regulatory pricing mechanism, broken interest rate transmission mechanism, not standardized benchmark interest rate formation mechanism, increasing risks of banks and enterprises and lack of risk control ability, faulty financial market development and financial supervision mechanism. To solve these obstacles faced by China's interest rate liberalization, the countermeasures are proposed as follow:

\section{A. Accelerating Reform of the Economic and Financial Systems to Provide A Sound Macroeconomic Environment}

Under new normal economy, macroeconomic development still needs to accelerate the reform of the economic system, explore new driving forces for economic development actively, change from factor driven and investment driven to innovation-driven, and realize the optimization of the economic structure with the tertiary industry and consumer demand as the main body. Moreover, it's necessary to carry out supply-side reform, address overcapacity, housing inventory and real estate inventory, reduce costs and deleverage strengthen financial risk prevention and control, and ensure stability and sustainability in a medium-high rate of economic growth.

\section{B. Building up a Multi-level Financial Market and Cultivating the Currency Market with Considerable Depth and Breadth}

According to these experiences of interest rate liberalization reform in various countries, developed financial market is the prerequisite and basis for the success of interest rate liberalization reform. At present, our country should vigorously develop non-banking institutions and direct financing, provide financial market participants with diversified investment varieties and risk management tools, and improve the short-term and long-term bonds, money market and capital market linkages, realize the free flow of funds, form relatively perfect term structure of interest rates, making all kinds of financial instruments carry on the reasonable pricing reference interest rate system and enhance the construction of the depth and breadth of financial markets. 
Conditions of Interest Rate Liberalization [J]. Financial Science, 2014,5:003.

[8] Cui Huifang, Zhao Wei. International Experience of Interest Rate Liberalization and China Selection [J]. Journal of Central China Normal University (Humanities and Social Sciences Edition),2014,53(4):29-36.

[9] Lai Huangping. Preliminary Study on Some Problems in China's Financial Market [J]. Foreign Economic and Trade,2013(10):105-106.

[10] Zhang Wanting. Motivation, Current Situation and Prospect of Interest Rate Liberalization in China [J]. Modern Business,2018(8).

[11] Zhang Shuai. Experience and Enlightenment of Interest Rate Liberalization in South Korea [J]. Economic Aspect, 2003(10):39-41.

[12] Shi Baoping, Bai Yongxiu. Quantitative Analysis of the Implementation Conditions of Interest Rate Liberalization and the Test of China [J]. Journal of Chang'an University (Social Science Edition), 2004,1:012.

[13] Wang Jian, Li Xinyi. Selection and Influence of Key Points of Interest Rate Liberalization Reform [J]. Bond,2018(6).

[14] Tao Xionghua, Chen Mingjue. Process Measurement and Reform Direction of Interest Rate Liberalization in China [J]. Journal of Zhongnan University of Economics and Law,2013(3):74-79.

[15] He Ye. Problems and Solutions in the Process of Interest Rate Liberalization in China [J]. China Market,2011(5):59-59.

[16] Zhou Tao. Discussion and Countermeasures on the Existing Problems of Interest Rate Liberalization in China [J]. Market Modernization, 2017(7):163-164.

\section{REFERENCES}

[1] Kong Lina, Zheng Xin. Experience of Interest Rate Liberalization in Latin American Countries and Enlightenment to China [J]. Southern Finance, 2011,4:011.

[2] Zhu Sixiang, Wang Jing. Analysis of Conditions for Interest Rate Liberalization in Developing Countries [J]. Journal of Economic Research, 2008(19):86-87.

[3] Zhang Yiming. Reference of Interest Rate Liberalization in Hong Kong to Market Interest Rate in Mainland China [J]. Daqing Social Sciences, 2018(1)

[4] Ba Shusong. Attention to Macroeconomic Adaptation to the Pace of Interest Rate Liberalization [J]. China Investment, 2015(1):109-109.

[5] Yuan Jun. Research on the Transformation of China's Macroeconomic Policies under the Economic New Normal [J]. China International Finance \& Economics (Chinese \& English),2017(14):168-169.

[6] Kong Weijia. Interest Rate Liberalization: Theoretical Basis, Practical Conditions and Realization Path [J]. Financial Economy,2016(12):5859.

[7] Xiao Wei. Is Now A Good Time Window for China's Deposit Interest Rate Liberalization - An Empirical Study Based on Macroeconomic 